\title{
PENGARUH KEBIJAKAN PERUBAHAN TARIF IMPOR TERHADAP SEKTOR KELAUTAN DAN PERIKANAN
}

\section{Effect of Import Tariff Change Policy on Marine and Fisheries Sector Performance}

\author{
*Mira dan Subechanis Saptanto \\ Balai Besar Riset Sosial Ekonomi Kelautan dan Perikanan \\ Gedung Balitbang KP I Lt. 4 \\ Jalan Pasir Putih Nomor 1 Ancol Timur, Jakarta Utara, Indonesia \\ Telp: (021) 64711583 Fax: 64700924 \\ Diterima tanggal: 3 April 2017 Diterima setelah perbaikan: 20 Mei 2017 \\ Disetujui terbit: 6 Juni 2017 \\ "email: miraclenia@yahoo.com
}

\begin{abstract}
ABSTRAK
Tujuan dari penelitian ini adalah melihat pengaruh kebijakan perubahan tarif impor terhadap kinerja sektor kelautan dan perikanan. Data tabel Input dan Output dianalisis dengan menggunakan Computable General Equilibrium (CGE). Simulasi dilakukan dengan tiga cara, pertama menggunakan tarif impor yang berlaku saat ini untuk produk perikanan sebesar $5 \%$, kedua menggunakan tarif impor $10 \%$ jika terjadi peningkatan tarif; dan ketiga menggunakan tarif $0 \%$ bila terjadi penurunan tarif impor disebabkan oleh kesepakatan kerjasama regional Masyarakat Ekonomi Asean (MEA). Hasil penelitian menunjukkan bahwa akibat pemberlakukan MEA terhadap kinerja makro sektor kelautan dan perikanan dapat meningkatkan pendapatan pemerintah (GDP) sebesar 0,009\%, dan ekspor 0,040\%. Kebijakan penurunan tarif impor akibat pemberlakuan MEA hanya berpengaruh negatif pada indikator neraca pembayaran, dimana penurunan tarif impor menyebabkan penurunan neraca pembayaran $0,070 \%$. Kebijakan penurunan tarif impor meningkatkan nilai tambah produk TTC, patin, kerapu, dan garam, masing-masing sebesar 0,047\%, 0,004\%, 0,003\%, dan 0,039\%. Selain itu, kebijakan penurunan tarif impor akibat pemberlakukan MEA menyebabkan ekspor TTC naik sebesar 3,367\%, sedangkan impor ikan kering dan olahan naik secara signifikan menjadi $11,498 \%$ dan $11,010 \%$. Sebaliknya kebijakan peningkatan tarif impor (menjadi sebesar 10\%) membuat penurunan pada output ikan kering dan ikan olahan impor masing-masing turun sebesar $18,502 \%$ dan $17,873 \%$. Kebijakan peningkatan tarif impor menyebakan peningkatan input produksi untuk ikan olahan dan ikan kering dimana masing-masing sebesar $32 \%$ dan $34,5 \%$. Dampak kebijakan peningkatan tarif impor terhadap input produk olahan selaras dengan tujuan kebijakan pengenaan tarif impor untuk meningkatkan nilai tambah komoditas, maka diharapkan pemerintah masih mengenakan tarif impor terutama untuk komoditas yang memiliki daya saing.
\end{abstract}

Kata Kunci: tarif, impor, CGE, kinerja, nilai tambah

\section{ABSTRACT}

This research was aimed to analyze the effect of import tariff change policy on marine and fisheries sector performance. Data of IO tables analyzed using CGE method. The simulation was conducted by three simulations, first, using current import tariff for fisheries product $5 \%$, secondly, using import tariff of $10 \%$ if there is increase of import tariff, and third, using tariff $0 \%$ where there is decrease of import tariff because agreement of ASEAN Economic Community (AEC). Result shown the implementation of AEC on the macro performance increased GDP by $0.009 \%$, and export by $0.040 \%$. The import tariff reduction negatively affects the balance of payments $(B O P)$ indicator, where leads to $0.070 \%$ decrease in the $B O P$. The import tariff reduction increases the added value of tuna alike, catfish, grouper and salt products by $0.047 \%, 0.004 \%, 0.003 \%$ and $0.039 \%$ respectively. In addition, the import tariff reduction policy caused TTC exports to increase by $3.367 \%$, while dry fish and fish processing imports increased significantly to $11.498 \%$ and $11.010 \%$. On the contrary, the policy to increase import tariff (10\% increasing), dried fish and imported fishes decreased by $18.502 \%$ and $17,873 \%$ respectively. The policy to increase import tariffs led to increased production inputs for processed fish and dried fish which were $32 \%$ and $34.5 \%$, respectively. The impact of the policy on increasing import tariffs on refined product inputs is in line with the objective of import tariff policy to increase commodity-added value, it is expected that the government still impose import tariffs, especially for competitively priced commodities.

Keywords: tariff, import, CGE, performance, value added 


\section{PENDAHULUAN}

Menurut Aprianto (2006) kebijakan pengenaan tarif pada komoditas akan meningkatkan harga barang di negara pengimpor dan menurunkan harga barang tersebut di negara pengekspor. Akibat perubahan harga tersebut, konsumen di negara pengimpor merugi dan konsumen di negara pengekspor memperoleh keuntungan. Kebijakan peningkatan tarif impor ditengarai dapat merangsang produsen domestik untuk meningkatkan produksinya. Menurut Winardi (2013), kebijakan peningkatan tarif impor akan meningkatkan pendapatan dan kesejahteraan produsen komoditas dalam negeri.

Sebaliknya, dari pihak importir mereka lebih cenderung kontra dengan kebijakan peningkatan tarif impor karena kekhawatiran mereka terhadap ketersediaan komoditas baiksecara kualitas maupun secara kuantitas. Karena menurut importir, jika tarif impor dinaikkan maka ketersediaan komoditas dalam negeri bisa terganggu, selain itu juga terjadi kenaikan harga barang karena kurangnya persediaan barang. Sedangkan kerugian bagi negara eksportir adalah terganggunya produksi domestiknya dan mereka mengangap negara importir melanggar ketentuan perdagangan bebas.

Kebijakan pengenaaan tarif impor berguna untuk melindungi konsumen dalam negeri dan untuk meningkatkan pendapatan negara. Kebijakan peningkatan tarif impor atau pengenaan tarif impor yang tinggi, biasanya dilakukan untuk sektor-sektor yang memiliki sumber daya seperti sektor perikanan. Kebijakan penurunan tarif impor biasanya untuk pemenuhan kebutuhan suplai dalam negeri akibat terjadinya kelangkaan komoditas. Kebijakan penurunan tarif impor karena juga berkaitan dengan isu liberalisasi perdagangan, khususnya untuk komoditas pertanian dan perikanan, seperti karena kesepakatan kerja sama regional seperti Masyarakat Ekonomi ASEAN (MEA). Dengan adanya liberalisasi perdagangan seperti pemberlakuan MEA (kerangka multilateral) pada sektor pertanian termasuk sub sektor perikanan akan mengubah pola perdagangan komoditas pertanian (Kasan, 2011). Pola perubahan tersebut bisa berdampak pada pengenaan/ pengurangan tarif impor, pajak ekspor, kuota ekspor dan kuota impor.

Salah satu dampak liberalisasi pada kawasan ASEAN adalah adanya Masyarakat Ekonomi ASEAN (MEA). MEA mengakibatkan penurunan tarif impor sampai pada $0 \%$, akan tetapi tidak semua komoditas memiliki tarif $0 \%$. Pada sektor perikanan, pada tahun 2014, kisaran tarif adalah 5-10\%, untuk ikan Tuna, Cakalang, Tongkol, Udang, Patin, Rumput Laut, dan Lele adalah $5 \%$. Kisaran pengenaan tarif yang $10 \%$ adalah terutama pada komoditas yang sudah memiliki nilai tambah seperti fillet ikan. Ada juga komoditas tertentu yang memiliki tarif $10 \%$ seperti komoditas kerapu dan nila. Ikan yang termasuk komoditas langka atau dilindungi dikenakan tarif maksimal yaitu sebesar $10 \%$. Bagaimana pengaruh peningkatan atau penurunan tarif impor terhadap kinerja sektor kelautan dan perikanan itulah tujuan dari penulisan makalah ini dengan menggunakan model keseimbangan umum.

\section{METODOLOGI}

\section{Model Keseimbangan Umum}

Pengaruh peningkatan atau penurunan tarif impor terhadap kinerja sektor kelautan dan perikanan menggunakan model keseimbangan umum. Model keseimbangan umum (general computable equilibrium - CGE) dalam analisis atau studi ekonomi merupakan model yang digunakan untuk mempelajari bagaimana kondisi penawaran dan permintaan berinteraksi dalam berbagai pasar secara simultan. Menurut Dixon et al. (1982) menyatakan bahwa model ekonomi keseimbangan umum melihat ekonomi sebagai suatu sistem keterkaitan antara pelaku ekonomi, yaitu: antara industri, rumah tangga, investor, pemerintah, importir dan eksportir, dan antar pasar komoditi yang berbeda dimana seluruh pasar yang ada dalam keadaan keseimbangan dan mempunyai struktur yang spesifik untuk mencapai keseimbangan.

Model keseimbangan umum (general equlibrium model) dapat diilustrasikan sebagai jembatan penghubung antara model ekonomi makro dan mikro. Dengan menggunakan model keseimbangan umum, analisis dampak kebijakan makro dan mikro dapat dilakukan secara serentak. Robinson (1989) mengemukakan bahwa model keseimbangan umum adalah sebuah model ekonomi yang paling relevan dalam penganalisisan dampak kebijakan pemerintah jika kinerja perekonomian negara cenderung menganut sistem pasar bebas, atau peran mekanisme pasar dalam perekonomian, negara semakin dominan. 
Ide mengenai komputasi keseimbangan umum (Computable General Equilibrium/ CGE) ini telah dicetuskan pada tahun 1758 oleh seorang ekonom dari Perancis bernama François Quesnay, dengan disusunnya Tableau économie. Namun oleh karena rumitnya tingkat komputasi yang dilakukan dalam penyusunan tabel tersebut, maka diperlukan waktu lebih dari satu abad, yaitu pada tahun 1874, agar tabel tersebut dapat dirampungkan secara utuh oleh Léon Walras. Walras inilah yang menjadi bapak dari teori keseimbangan umum, sehingga teori tersebut sering juga disebut dengan istilah Walrasian Economics. Menurut Hulu (1995), pengembangan model keseimbangan umum dimulai dari formulasi teoritik sejak pertengahan abad ke-19, antara lain rumusan Gossen (1854) Jevons (1871), Walras (1974-1877), Menger (1871), Abraham Wald (1930-an), Cassel (1930-an), walaupun masih belum lengkap pembuktian eksistensi solusinya, tetapi berhasil menyusun formulasi model keseimbangan umum sebagai sebuah model keseimbangan umum versi Walras. Kemudian, John von Neumann membuktikan bahwa keseimbangan umum adalah terbukti eksis (ada) sebagai sebuah model dan mampu menghasilkan solusi tunggal, demikian pula dengan John Hicks dan Oscar Lange menyusun model keseimbangan umum versi makro ekonomi Keynesian. Kemudian pada tahun 1950-ani Arrow, Debreu dan McKenze berhasil membuktikan bahwa model keseimbangan umum, secara teoritus terbukti eksis (ada), memiliki solusi tunggal dan stabil.

Sejalan dengan itu, dalam periode 19301950-an cukup pesat perkembangan model keseimbangan umum terapan (Applied General Equilibrium / AGE Mode/), seperti model inputoutput Leontief (1930-an), model Neraca Sosial Ekonomi atau Social Accounting Matrix (SAM). Perlu dijelaskan bahwa model keseimbangam umum terapan bukanlah aplikasi dari model keseimbangan umum teoritis hasil rumusan seperti yang dijelaskan di atas. Walaupun demikian, pada periode setelah tahun 1950-an, data pendukung model keseimbangan umum terapan (seperti data input-output dan SNSE/ SAM) dapat dimanfaatkan sebagai pendukung model keseimbangan umum terapan.

Beberapa keunggulan model CGE dibandingkan dengan model ekonomi lainnya, antara lain adalah (Oktaviani, 2011; Wibowo, 2009):
1. Dibandingkan dengan model keseimbangan parsial, model CGE sudah memasukkan semua transaksi antara pelaku-pelaku ekonomi secara keseluruhan, baik di pasar faktor produksi maupun pasar komoditi. Sehingga dampak dari suatu kebijakan dapat dianalisis pengaruhnya secara kuantitatif terhadap kinerja ekonomi baik secara ekonomi makro maupun ekonomi sektoral.

2. Model CGE sudah memasukkan kemungkinan substitusi antar faktor produksi, sehingga jika terjadi perubahan harga relatif suatu faktor produksi, maka produsen akan merubah komposisi penggunaan faktor produksi ke arah faktor produksi yang harganya relatif lebih murah. Pada model CGE, dampak kebijakan dapat dianalisis pada tingkat institusi, distribusi pendapatan antar golongan rumah tangga, distribusi pendapatan antar faktor produksi primer, neraca perdagangan dan sebagainya dibandingkan dengan SNSE atau Social Accounting Matrix (SAM), model CGE sudah memasukkan persamaan nonlinear. Disamping itu, pada model CGE harga sudah dimasukkan sebagai peubah endogen.

3. Dibandingkan dengan model makro ekonometrika, model CGE dapat mengacu pada tahun tertentu (particular benchmark years), sedangkan pada model makro ekonometrika data yang digunakan merupakan data deret waktu (time series), sehingga tidak dapat diaplikasikan pada tahun tertentu. Disamping itu dengan menggunakan model CGE hubungan antara ekonomi makro dangan mikro ekonomi dapat diketahui, sementara pada model makro ekonometrika analisis dampak hanya dapat dilakukan di tingkat makro.

4. Model CGE dapat mengatasi permasalahan ketersediaan data deret waktu yang terbatas, terutama di negara berkembang dan inkonsistensi data yang diperlukan model makro ekonometrika maupun model simultan. Pencatatan data dan keakuratan data dari waktu ke waktu di negara berkembang saat ini masih menjadi kendala untuk ketersediaan data yang lengkap.

5. Model CGE memiliki landasan mikroekonomi yang kuat yang dapat membantu dalam menginterpretasikan hasil simulasi atau analisis faktual. Hal ini dimungkinkan karena model CGE memuat spesifikasi lengkap 
mengenai penawaran dan permintaan di semua pasar serta perilaku dari semua pelaku ekonomi (Robinson, 1989)

6. Model CGE dapat melakukan analisis dampak kebijakan terhadap semua sektor ekonomi secara simultan. Sedangkan, model Input - Output hanya dapat menganalisis dampak kebijakan di tingkat industri. Berbeda dengan model Input - Output, model CGE memasukkan harga sebagai variabel endogen sehingga substitusi antar faktor produksi dapat dilakukan di dalam model (Horison, 1997 dalam Taufikurohman, 2004).

7. Model CGE dapat melakukan analisis berdasarkan data tahun tertentu (particular benchmark years), sedangkan model ekonometrika sangat mengandalkan data deret waktu (time series).

Dalam model keseimbangan umum (CGE), keseimbangan ekonomi makro di masing-masing pasar dapat diilustrasikan seperti dalam Gambar 1 yang diadopsi dari Devarajan et al. (1990) seperti yang dikutip oleh Sadoulet dan Janvry (1995).

Gambar 1 mengilustrasikan kondisi keseimbangan di berbagai pasar yang dicerminkan oleh keempat kuadran. Diasumsikan bahwa seluruh faktor produksi digunakan secara penuh (full employment), tingkat produksi agregat ditunjukkan oleh kurva kemungkinan produksi frontier yang terletak pada kuadran IV, yang mencerminkan kemungkinan transformasi antara tujuan pasar ekspor $(E)$ dan tujuan pasar domestik $(D)$. Barang yang diekspor $(E)$ digunakan untuk mendapatkan barang impor $(M)$ melalui transaksi perdagangan di pasar pertukaran luar negeri (foreign exchange market) yang dicerminkan di kuadran I, dimana hubungan di antara kedua barang tersebut menghasilkan neraca perdagangan (balance of trade). Barang produksi domestik yang tidak diekspor dijual di pasar domestik yang dilukiskan pada kuadran III. Korespondensi dengan ketiga kuadran tersebut, tingkat konsumsi frontier di kuadran II dipasok dari kombinasi barang domestik (D) dan impor $(M)$.

Pada kuadran I diasumsikan tidak ada foreign capital inflow dan harga ekspor maupun impor adalah sama yang dilukiskan oleh lereng garis balance of trade sebesar satu. Pada kuadran II, kecuraman kurva utilitas merupakan fungsi dari tingkat konsumsi frontier pada titik $C$ dan harga relatif keseimbangan $P^{D} / P^{M}$. Sedangkan pada sisi produksi di kuadran IV yang berkaitan dengan tingkat produksi sebesar $P$, dimana kecuraman slope kurva kemungkinan produksi frontier ditentukan oleh harga relatif barang ekspor dan domestik, $P^{E} / P^{D}$. Selanjutnya, solusi keseimbangan ekonomi makro dalam model ini dapat diamati pada kuadran II yang menunjukkan perilaku permintaan konsumen, yaitu tingkat utilitas tertentu pada saat konsumsi sebesar $C$ dan tingkat produksi sebesar $P$. Dalam model keseimbangan umum, berbagai pasar saling terkait satu dengan lainnya dalam suatu perekonomian, sehingga perubahan pada satu pasar akan berpengaruh pada pasar lainnya. Keseimbangan umum akan tercapai bila permintaan dan penawaran pada masingmasing pasar berada dalam keseimbangan.

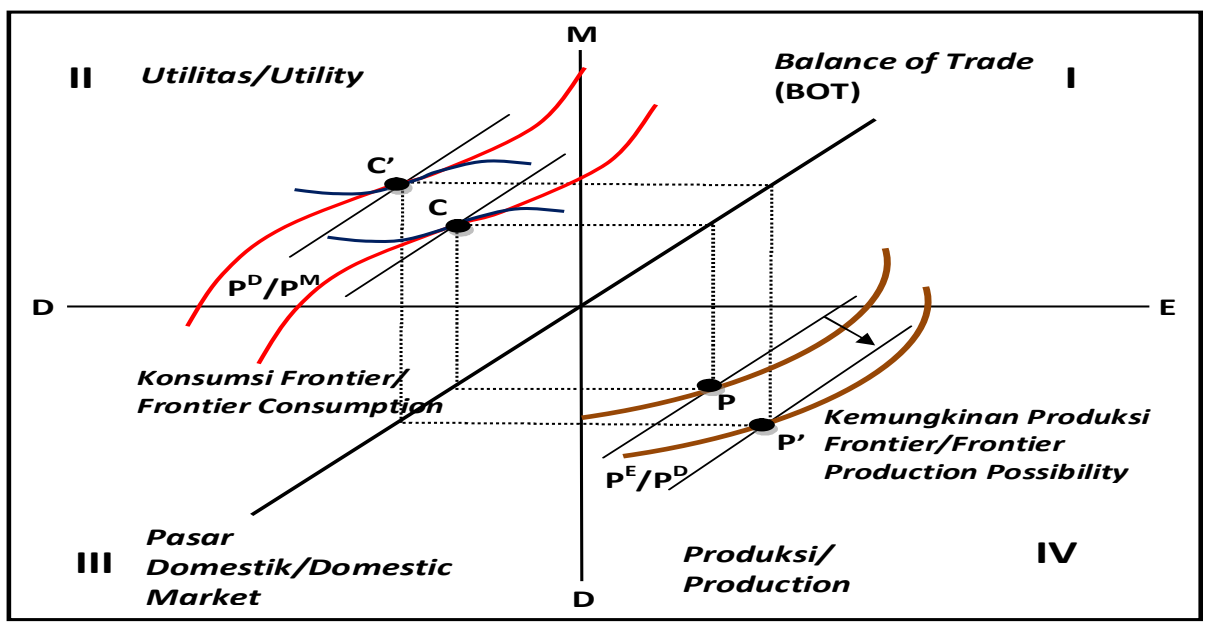

Gambar 1. Keseimbangan Ekonomi Makro dalam Model CGE Figure 1. Macroeconomic Balance in the CGE Model

Sumber: Sadoulet dan de Janvry (1995)/Source: Sadoulet and de Janvry (1995) 
Di dalam sistem pasar persaingan sempurna, semua perilaku antar pelaku ekonomi dilakukan melalui mekanisme pasar. Perilaku pelakupelaku ekonomi ditentukan semata-mata untuk kepentingan peribadi. Setiap pelaku, baik bertindak sebagai pembeli maupun penjual tidak memiliki kemampuan untuk mempengaruhi harga yang berlaku di pasar. Keseimbangan umum di dalam sistem multi pasar tercapai jika keputusan yang dibuat pembeli-pembeli dan penjual-penjual saling bersesuaian pada tingkat harga tertentu dan berlaku secara simultan di setiap pasar.

Pada model keseimbangan umum berlaku hukum Walras yang menyatakan bahwa semua harga dan kuantitas barang di semua pasar ditentukan secara simultan melalui proses interaksi satu pasar dengan pasar lainnya (Nicholson, 2002). Oleh karena itu dalam konsep hukum Walras, excess demand $(E D)$ di pasar $j$ dapat didefinisikan sebagai:

$z_{j}(p)=\sum_{i=1}^{n} x_{j}^{i}\left(p, p \cdot e^{i}\right)-\sum_{i=1}^{n} e_{j}^{i} ; j=1,2,3, \cdots, n$

Keseimbangan umum tercapai bila $E D$ memenuhi hukum Walras yang menyatakan bahwa nilai dari ED agregat selalu nol pada semua vektor harga. Artinya, bahwa pada suatu saat akan terdapat sebuah vektor harga-harga yang dapat menyeimbangkan tingkat permintaan dan penawaran di tiap pasar komoditas sehingga didapatkan hasil derivasi hukum Walras, yaitu:

$p x=$ pe menjadi $p(x-e)=0$

ED di setiap pasar dengan permintaan $x^{\prime}\left(p, p . e^{\prime}\right)$ :

$\sum_{j=1}^{n} p_{j}\left[x_{j=1}^{i}\left(p, p . e^{i}\right)-e_{j}^{i}\right]=0$

ED bagi setiap pelaku pasar di setiap pasar:

$$
\begin{aligned}
& \sum_{i=J}^{m} \sum_{j=1}^{n} p_{j}\left[x_{j=1}^{i}\left(p, p . e^{i}\right)-e_{j}^{i}\right]=0 \\
& \sum_{j=1}^{n} p_{j}\left\{\sum_{i=1}^{m}\left[x_{j=1}^{i}\left(p, p . e^{i}\right)-e_{j}^{i}\right]\right\}=0
\end{aligned}
$$

Dengan mengganti faktor kedua pada Persamaan (4) dengan Persamaan (5), maka diperoleh persamaan hukum Walras sebagai:

$\sum_{j=1}^{n} p_{j} z_{j}(p)=0$

\section{Sumber Data dan Teknik Analisis Data}

Model keseimbangan umum ini biasanya digunakan untuk analisis perubahan kebijakan ekonomi makro maupun sektoral di berbagai negara. Model ini disebut juga model keseimbangan umum, dimana keseimbangan umum tercapai bila permintaan dan penawaran pada masing-masing pasar berada dalam keseimbangan. Keseimbangan umum dalam model CGE (Computable General Equilibrium) dicerminkan dalam bentuk nominal (kuantitas dikalikan dengan harga) yang mewakili aliran dana, baik disertai dengan aliran barang (transaksi) maupun tidak, model CGE terdiri dari persamaan-persamaan yang mewakili keseimbangan seluruh pasar mulai dari pasar input sampai pasar output untuk keseluruhan sektor yang dianalisis.

Data yang digunakan dalam penelitian ini adalah data sekunder berupa data input-output (I-O) yang bersumber dari Biro Pusat Statistik (BPS). Pada Tabel I-O yang diterbitkan BPS tersebut, sektor perikanan belum terdisagregasi menurut komoditas yang diinginkan dibuat dalam model. Selain itu juga butuh data primer yang dikumpulkan dengan wawancara untuk memverifikasi FGD (Focus Group Discussion) yang dilakukan pada tahun lalu. Pengumpulan data primer dilakukan selama tiga kali, dimana tujuannya untuk melengkapi basis data untuk membangun model kebijakan pembangunan kelautan dan perikanan. Data primer yang terkumpul meliputi data input produksi dari usaha penangkapan Tuna, Tongkol, dan Cakalang, data input produksi dari usaha budidaya patin, kerapu, dan rumput laut, udang dan data input produksi dari usaha tambak garam, dan data input produksi dari usaha ikan olahan dan ikan kering. FGD dilakukan di Hotel Santika, dimana pihak yang hadir adalah perwakilan dari Dirjen Perikanan Budidaya, Dirjen Perikanan Tangkap, Dirjen Pengolahan Produk dan Pemasaran, Pusat Penelitian Sosial Ekonomi Pertanian, Sekretariat Badan Litbang KKP, Badan Pusat Statistik Jakarta, Bagian Program dari Sekretariat Jenderal KKP.

\section{Dasar Simulasi}

Asumsi pertama untuk dasar simulasi adalah tarif impor sebelum pemberlakuan kebijakan Masyarakat Ekonomi ASEAN (MEA) yaitu sebesar $5 \%$ (2014). Asumsi kedua yaitu untuk tahun 2015, dimana telah diberlakukannya kebijakan Masyarakat Ekonomi ASEAN (tarif 0\%). Asumsi 
ketiga yaitu jika tarif impor dinaikkan untuk negara di luar ASEAN dan pengimpor bahan olahan yaitu sebesar 10\%. Pada tahun 2014, kisaran tarif adalah 5-10\%, untuk ikan Tuna, Cakalang, Tongkol, Udang, Patin, Rumput Laut, dan Lele adalah 5\%. Kisaran pengenaan tarif yang $10 \%$ adalah terutama pada komoditas yang sudah memiliki nilai tambah seperti filet ikan. Ada juga komoditas tertentu yang memiliki tarif $10 \%$ seperti komoditas kerapu dan nila.

Pemberlakuan kebijakan Masyarakat Ekonomi ASEAN (MEA), pada satu sisi melahirkan peluang, di sisi lain juga menjadi satu tantangan. Tantangan dari pemberlakuan kebijakan MEA adalah kemampuan komoditas Indonesia bersaing dengan komoditas dari negara lain yang yang masuk pada urutan teratas pada global competitiveness index. Tantangan dari pemberlakuan kebijakan MEA adalah peringkat Indonesia menurut global competitivenes index masih berada pada posisi ke-38 dari 148 negara. Sedangkan negara tetangga seperti Singapura (peringkat 2), Malaysia (peringkat 24), dan Thailand berada posisi di bawah Indonesia pada peringkat 37 (Wangke, 2014).

Tantangan dari pemberlakuan kebijakan MEA menurut Wangke (2014) adalah Indonesia hanya sebagai pemasok bahan baku, defisit perdagangan semakin meningkat, jumlah tenaga kerja asing semakin meningkat, dan banyak pemodal asing. Indonesia hanya sebagai pemasok bahan baku karena komoditas Indonesia nilai tambahnya kecil dan daya saingnya tinggi. Sebagai contoh untuk komoditas rumput laut, negara Indonesia hanya mengekspor bahan baku. Sedangkan untuk produk olahan rumput laut posisi Indonesia adalah pengimpor dimana trennya dari tahun 2003 sampai dengan tahun 2012 mengindikasikan peningkatan volume impor.

\section{HASIL DAN PEMBAHASAN}

\section{Kinerja Makro Ekonomi}

Penurunan tarif impor mengakibatkan kinerja ekonomi makro Indonesia membaik, seperti peningkatan pendapatan pemerintah (GDP) dan ekspor, kecuali untuk indikator neraca pembayaran (TOT). Pemberlakuan tarif $0 \%$ untuk negara ASEAN (penurunan tarif 5\%) mengakibatkan peningkatan pendapatan pemerintah sebesar 0,009\%, peningkatan ekspor $0,040 \%$, dan penurunan neraca pembayaran $0,070 \%$. Penurunan tarif impor berdampak positif pada ekonomi makro kelautan dan perikanan (GDP dan Ekspor), karena menurut Karyasa (2003), penurunan tarif impor menyebabkan komoditas pertanian, termasuk salah satunya komoditas perikanan, memiliki daya saing. Penurunan tarif impor, memaksa industri perikanan melakukan efisiensi biaya produksi supaya memiliki daya saing dengan komoditas perikanan yang diimpor dari negara lain. Penurunan tarif impor pada

Tabel 1.Tarif Impor Beberapa Komoditas Perikanan Pada Tahun 2014.

Table 1. Import Rates of Some Fisheries Commodities In 2014.

\begin{tabular}{|c|c|c|}
\hline Pos/Subpos & Uraian Barang/ Commodities & $\begin{array}{l}\text { Tarif Imporl } \\
\text { Import Tariff }(\%)\end{array}$ \\
\hline 0302.34 .00 .00 & - - Ikan tuna mata besar/ Big eye tuna (Thunnus obesus) & 5 \\
\hline 0302.35 .00 & $\begin{array}{l}\text { - - Ikan tuna sirip biru Atlantik dan Pasifik/ Atlantic and Pacific } \\
\text { bluefin tuna (Thunnus thynnus, Thunnus orientalis): }\end{array}$ & 5 \\
\hline 0302.35 .00 .10 & $\begin{array}{l}\text { - - Ikan tuna sirip biru Atlantik/ Atlantic bluefin tuna (Thunnus } \\
\text { thynnus) }\end{array}$ & 5 \\
\hline 0302.35 .00 .20 & $\begin{array}{l}\text { - - - Ikan tuna sirip biru Pasifik/ Pacific bluefin tuna (Thunnus } \\
\text { orientali) }\end{array}$ & 5 \\
\hline 0302.36 .00 .00 & $\begin{array}{l}\text { - - Ikan tuna sirip biru Selatan/ Southern bluefin tuna } \\
\text { (Thunnus maccoyii) }\end{array}$ & 5 \\
\hline 0302.72 .90 .10 & - - - - Ikan patin/ Catfish (Pangasius spp.) & 5 \\
\hline 0302.72 .90 .20 & - - - Ikan lele/ Catfish (Clarias spp.) & 5 \\
\hline 0306.17 .10 & - - - Udang windu/ Freshwater prawn (Penaeus monodon): & 5 \\
\hline 0306.17 .20 & $\begin{array}{l}\text { - - - Udang vanamei/ Vannamei shrimp (Liptopenaeus } \\
\text { vannamei): }\end{array}$ & 5 \\
\hline
\end{tabular}

Sumber: Kementerian Keuangan, 2014/ Source : Minstry of Finance, 2014 
awalnya memang mengurangi pendapatan negara, namun secara jangka panjang akan meningkatkan GDP karena peningkatan ekspor dan pertumbuhan industri yang berdaya saing.

Sebaliknya peningkatan tarif impor sebesar $5 \%$ (menjadi 10\%) malah menurunkan pendapatan pemerintah sebesar $0,200 \%$, menurunkan ekspor sebesar $0,076 \%$, menurunkan impor sebesar $0,180 \%$. Peningkatan tarif impor malah kontraproduktif, karena menyebabkan pengurangan surplus konsumen, peningkatan surplus produsen, dan terjadi in efisiensi produksi dan in efisiensi ekonomi. In efisiensi produksi dan in efisiensi ekonomi komoditas perikanan, karena industri perikanan yang berkembang tidak memiliki daya saing. Pada awal peningkatan tarif impor, memang penerimaan pemerintah akan meningkat, akan tetapi setelah mencapai equlibrium, penerimaan pemerintah akan menurun dan berlawanan dengan kenaikan tarif impor yang diberlakukan (Karyasa, 2003).

\section{Impor}

Pada tabel 3 terlihat bahwa ketika tarif impor dinaikkan, maka impor ikan kering dan ikan lahan menurun sangat signifikan, misalnya pada ikan kering dan ikan olahan impor masing-masing produk turun sebesar $18,502 \%$ dan $17,873 \%$. Sebaliknya, jika pemberlakuan MEA dimana tarif impor negara ASEAN adalah 0\%, artinya penurun tarif impor sebesar 5\%, maka impor perikanan ikan kering dan ikan olahan naik secara signifikan menjadi $11,498 \%$ dan $11,010 \%$. Artinya, produk perikanan Indonesia yang di dalam negeri belum memiliki nilai tambah tinggi, sehingga ketika ada kebijakan penurunan tarif impor berdampak pada peningkatan permintaan produk olahan perikanan.
Selama kurun waktu sepuluh tahun (2002-2012) rata-rata peningkatan impor sebesar $14,74 \%$. Jika dilihat dari komoditas unggulan peningkatan rata-rata impor selama sepuluh tahun, seperti udang $(92,29 \%)$, Tuna Tongkol dan Cakalang $(89,36 \%)$, dan rumput laut $(29,17 \%)$. Peningkatan volume naik secara signifikan dari tahun 2008 sampai dengan tahun 2011, dimana masing-masing kenaikan adalah sebesar 280.179 ton, 331.893 ton, 369.282 ton, dan 431.871 ton (Gambar 2).

Salah satu hal yang menarik dari impor perikanan dan kelautan, adalah untuk produk rumput laut, posisi Indonesia adalah impor tersebut banyak berupa produk olahan yang sudah memiliki nilai tambah. Misalnya pada tahun 2010, nilai impor rumput mentah adalah sebesar US\$ 1.499.110, sedangkan untuk nilai impor rumput laut olahan adalah sebesar US\$ 3.305.460. Hal ini mengindikasikan bahwa untuk komoditas rumput laut nilai tambah yang dihasilkan dari produk domestik masih kecil, sehingga untuk memenuhi kebutuhan bahan baku yang sudah bersifat olahan masih diimpor dari negara lain seperti Jerman, Cina, dan negara lainnya.

\section{Ekspor}

Pada Tabel 4, terlihat ketika menggunakan data baseline (rata-rata tarif impor pada November 2014 sebesar 5\%) maka dampak terhadap ekspor TTC adalah terjadi penurunan sebesar 3,296\%. Jika disimulasikan kebijakan tarif impor ketika Masyarakat Ekonomi ASEAN diberlakukan pada tahun 2015, dimana tarif impor untuk negara ASEAN adalah $0 \%$, artinya tarif impor turun $5 \%$ maka ekspor TTC naik sebesar $3,367 \%$

Tabel 2. Dampak Perubahan Tarif Impor Terhadap Kinerja Makro Ekonomi (\%). Table 2. Impact of Changes on Import Tariffs on Macroeconomic Performance (\%).

\begin{tabular}{lccc}
\hline \multirow{2}{*}{$\begin{array}{c}\text { Deskripsi/ } \\
\text { Description }\end{array}$} & \multicolumn{3}{c}{$\begin{array}{c}\text { Simulasi Dampak Perubahan tarif Impor/ } \\
\text { Impact Simulation of Change of Import tariff }\end{array}$} \\
\cline { 2 - 4 } & $\begin{array}{c}\text { Baseline (5\%)/ } \\
\text { Baseline (5\%) }\end{array}$ & $\begin{array}{c}\text { Simulasi 1 (10\%)/ } \\
\text { Simulation 1 }\end{array}$ & $\begin{array}{c}\text { Simulasi 2 } \\
\mathbf{( - 5 \% ) / ~} \\
\text { Simulation 2 }\end{array}$ \\
\hline GDP/ GDP & -0.100 & -0.200 & 0.009 \\
TOT/ TOT & 0.070 & 0.014 & -0.070 \\
Ekspor/ Export & -0.039 & -0.076 & 0.040 \\
Impor/ Import & -0.093 & -0.180 & 0.099 \\
\hline
\end{tabular}

Sumber: Data I-O 175 sektor yang diagregasi menjadi 75 sektor (diolah)/

Source : I-O data 175 sectors aggregated to 75 sectors (processed) 
Tabel 3. Dampak Perubahan Tarif Impor Terhadap Impor Perikanan (\%).

Table 3. Impact of Changes on Import Tariff on Fisheries Imports (\%).

\begin{tabular}{lccc}
\hline \multirow{1}{*}{$\begin{array}{c}\text { Deskripsi/ } \\
\text { Description }\end{array}$} & \multicolumn{2}{c}{$\begin{array}{c}\text { Simulasi Dampak Penurunan/Kenaikan Tarif Impor/ Impact } \\
\text { Simulation of Increase or Decrease in Import Tariff Increase }\end{array}$} \\
\cline { 2 - 4 } & $\begin{array}{c}\text { Baseline (5\%) } \\
\text { Baseline (5\%) }\end{array}$ & $\begin{array}{c}\text { Simulasi 1 (10\%)/ } \\
\text { Simulation 1 }\end{array}$ & $\begin{array}{c}\text { Simulasi 2 (-5\%/ } \\
\text { Simulation 2 }\end{array}$ \\
\hline Tuna, Tongkol, dan Cakalang/ Tuna & -4.747 & -9.083 & 5.217 \\
Ikan Tangkap Laut Lainnya/ & & & \\
Fisheries Catch & -5.017 & -9.599 & 5.516 \\
Patin/ Catfish & -5.092 & -9.737 & 5.605 \\
Kerapu/ Grouper & -5.085 & -9.723 & 5.596 \\
Rumput Laut/ Seaweed & -5.085 & -9.723 & 5.596 \\
Ikan budidaya lainnya/ Aquaculture & -5.085 & -9.723 & 5.596 \\
Udang/ Prawn & -5.037 & -9.636 & 5.540 \\
Garam/ Salt & -0.081 & -0.155 & 0.089 \\
Ikan kering/ Dried fish & -9.910 & -18.502 & 11.498 \\
Ikan olahan/ Processing fisheries & -9.548 & -17.873 & 11.010 \\
\hline
\end{tabular}

Sumber: Data I-O 175 sektor yang diaggregasi menjadi 75 sektor (diolah)/

Source : I-O data 175 sectors aggregated to 75 sectors (processed)

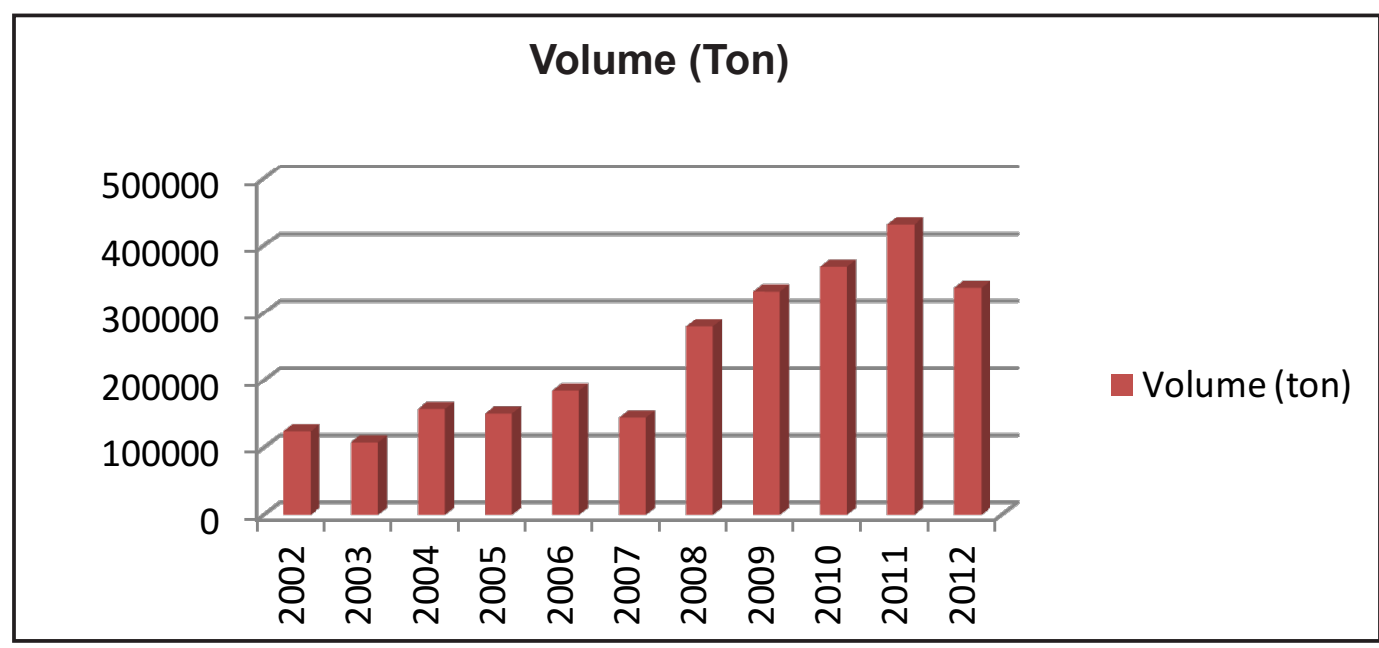

Gambar 2. Volume Impor Perikanan Dari Tahun 2002-2012

Figure 2. Fisheries Import Volume, 2002-2012

Sumber: Pusdatin, 2014/Source: Pusdatin, 2014

Salah satu hal yang menarik adalah ketika pemberlakuan kebijakan MEA, industri perikanan yang diuntungkan adalah ekspor pada industri pengolahan. Halini disebabkan kebijakan penurunan tarif menjadi $0 \%$ yang dulunya $5 \%$, meningkatkan ekspor pengolahan ikan sebesar $66,17 \%$. Menurut Yonariza dan Mahdi (2013), dampak kerjasama regional misalnya MEA atas komoditi pada Kuadran I (komoditas yang masuk dalam sektor pertanian) akan terjadi penciptaan nilai tambah dan kerjasama teknologi pengolahan untuk komoditas ekspor.
Di sini akan terjadi transformasi, posisi Negara ASEAN yang sebelumnya berkompetisi untuk memenuhi pasar dunia, dengan adanya MEA, negara-negara ini akan menjalin kemitraan (Yonariza dan Mahdi, 2013). Kerjasama antara pelaku usaha di kawasan ASEAN memiliki efek pada peningkatan skala usaha, manajemen, dan teknologi yang pada akhirnya negara dalam kawasan MEA berintegrasi memproduksi komoditas yang kompetitif dalam perekonomian dunia. 
Tabel 4. Dampak Perubahan Tarif Impor Terhadap Ekspor Perikanan (\%). Table 4. Impact of Changes on Import Tariff on Fisheries Export (\%).

\begin{tabular}{lccc}
\hline \multirow{1}{*}{$\begin{array}{c}\text { Deskripsi/ } \\
\text { Description }\end{array}$} & \multicolumn{2}{c}{$\begin{array}{c}\text { Simulasi Dampak Penurunan/Kenaikan Tarif Impor/Impact } \\
\text { Simulation of Increase or Decrease in Import Tariff Increase }\end{array}$} \\
\cline { 2 - 4 } & $\begin{array}{c}\text { Baseline (5\%)/ } \\
\text { Baseline (5\%) }\end{array}$ & $\begin{array}{c}\text { Simulasi 1 (10\%)/ } \\
\text { Simulation 1 }\end{array}$ & $\begin{array}{c}\text { Simulasi 2 (-5\%/ } \\
\text { Simulation 2 }\end{array}$ \\
\hline Tuna, Tongkol, dan Cakalang/ TTC & -3.296 & -6.529 & 3.367 \\
Ikan Tangkap Laut Lainnya/ Fisheries & & & 3.240 \\
Catch & -2.981 & -5.731 & 0.012 \\
Kerapu/ Grouper & -0.011 & -0.022 & 0.209 \\
Rumput Laut/ Seaweed & -0.189 & -0.361 & 0.891 \\
Ikan budidaya lainnya/ Aquaculture & -0.807 & -1.539 & 0.101 \\
Udang/ Prawn & -0.923 & -0.178 & 4.208 \\
Ikan kering/ Dried fish & -3.837 & -7.351 & 66.117 \\
Ikan olahan/ Processing fisheries & -60.972 & -117.406 & \\
\hline
\end{tabular}

Sumber: Data I-O 175 sektor yang diagregasi menjadi 75 sektor (diolah)/

Source : I-O data 175 sectors aggregated to 75 sectors (processed)

\section{Input}

Faktor input yang harus diperhatikan dalam pemberlakuan kebijakan MEA adalah komponen BBM untuk nelayan yang Indonesia adalah statusnya pengimpor. Pemerintah memberikan subsidi BBM untuk nelayan sebesar $3 \%$ dari total subsidi yang diberikan pemerintah. Selain itu adalah pakan untuk budidaya kerapu dan patin yang statusnya juga adalah impor. Selain pakan, BBM, hal yang harus diperhatikan saat penerapan kebijakan MEA adalah penggunaan ABK (tenaga kerja) pada industri perikanan tangkap. Menurut (Pratiwi, 2012) ketimpangan antara permintaan dan penawaran tenaga kerja harus diwaspadai saat pemberlakuan kebijakan MEA.

Pada Tabel 5 terlihat bahwa penurunan tarif impor menyebabkan permintaan input tenaga kerja sektor pengolahan perikanan meningkat sebesar $0,320 \%$. Hal ini disebabkan peningkatan industri pengolahan untuk meningkatkan nilai tambah perikanan, sehingga kebutuhan tenaga kerja semakin tinggi.

Peningkatan tarif impor menjadi sebesar $10 \%$ menyebabkan penurunan pada input perikanan pada sektor primer, yaitu penurunan masingmasing pada input TTC $(0,193 \%)$, udang $(0,007)$,

Tabel 5. Dampak Perubahan Tarif Impor Terhadap Input Perikanan (\%).

Table 5. Impact of Changes on Import Rates on Fisheries Input (\%).

\begin{tabular}{lccc}
\hline \multicolumn{1}{c}{$\begin{array}{c}\text { Deskripsi/ } \\
\text { Description }\end{array}$} & \multicolumn{2}{c}{$\begin{array}{c}\text { Simulasi Dampak Penurunan/Kenaikan Tarif Impor/ Impact } \\
\text { Simulation of Increase or Decrease in Import Tariff Increase }\end{array}$} \\
\cline { 2 - 4 } & $\begin{array}{c}\text { Baseline (5\%)/ } \\
\text { Baseline (5\%) }\end{array}$ & $\begin{array}{c}\text { Simulasi 1 (10\%)/ } \\
\text { Simulation 1 }\end{array}$ & $\begin{array}{c}\text { Simulasi 2 (-5\%)/ } \\
\text { Simulation 2 }\end{array}$ \\
\hline Tuna, Tongkol, dan Cakalang/ Tuna & -0.096 & -0.193 & 0.095 \\
Ikan Tangkap Laut Lainnya/ Fisheries & & & -0.029 \\
Catch & 0.026 & 0.050 & 0.007 \\
Patin/ Catfish & -0.008 & -0.015 & 0.003 \\
Kerapu/ Grouper & -0.003 & -0.007 & 0.003 \\
Rumput Laut/ Seaweed & -0.003 & -0.007 & 0.003 \\
Ikan budidaya lainnya/ Aquaculture & -0.003 & -0.007 & 0.002 \\
Udang/ Prawn & -0.003 & -0.007 & 0.126 \\
Garam/ Salt & -0.118 & -0.228 & -0.207 \\
Ikan kering/ Dried fish & 0.183 & 0.345 & -0.194 \\
Ikan olahan/ Processing fisheries & 0.0170 & 0.320 & \\
\hline
\end{tabular}

Sumber: Data I-O 175 sektor yang diagregasi menjadi 75 sektor (diolah)/

Source : $1-O$ data 175 sectors aggregated to 75 sectors (processed) 
dan garam $(0,228)$. Peningkatan tarif impor sebesar $5 \%$ pada input garam sangat berpengaruh $(22,8 \%)$, hal ini menandakan bahwa untuk produk garam, impor masih mendominasi. Sedangkan untuk produk ikan kering dan ikan olahan, peningkatan tarif impor malah menyebabkan peningkatan input pada produk olahan dan ikan kering. Hal ini selaras dengan tujuan pengenaan tarif impor untuk meningkatkan nilai tambah produk dalam negeri.

\section{Output}

Pengaruh penurunan tarif impor dalam rangka penerapan MEA adalah output perikanan, terutama output pengolahan dan ikan kering. Pada Tabel 6 di bawah ini terlihat bahwa penurunan tarif impor berdampak pada penurunan output produk pengolahan perikanan $(0,073 \%)$ dan produk ikan kering sebesar 0,067\%. Hal ini disebabkan karena sektor kelautan dan perikanan masih memproduksi bahan baku, belum memproduksi produk yang bernilai tambah tinggi seperti ikan olahan. Akibat lanjutannya adalah saat penurunan tarif impor maka produksi ikan olahan dan kering menjadi turun, karena kalah bersaing dengan produk impor ikan olahan. Kebijakan Menteri Kelautan dan Perikanan, mengenai mengurangi investasi asing pada sektor perikanan tangkap, dan meningkatkan kerja sama investasi asing pada sektor pengolahan perikanan, hal ini dipandang tepat, karena untuk meningkatkan nilai tambah industri perikanan Indonesia.
Salah satu hal yang menarik adalah pemberlakuan kebijakan MEA dengan pemberlakuan tarif $0 \%$ yang sebelumnya $5 \%$ pada komoditas tertentu seperti pada komoditas TTC (Tuna, Tongkol, dan Cakalang), dimana setelah penerapan kebijakan MEA terjadi peningkatan output sebesar 0,047\%. Hal ini dikarenakan terjadi efek pada peningkatan skala usaha, manajemen, dan teknologi pada usaha TTC akibat pemberlakuan MEA.

Penurunan tarif impor menyebabkan peningkatan nilai tambah untuk produk perikanan, kecuali ikan tangkap laut lainnya dan ikan olahan/ kering. Penurunan tarif impor sebesar 5\% menyebabkan peningkatan nilai tambah produk TTC, patin, kerapu, dan garam, masing-masing sebesar 0,047\%,0,004\%,0,003\%, dan 0,039\%. Peningkatan nilai tambah produk perikanan merupakan dampak prositif dari penerapan MEA. Hal ini mengindikasikan bahwa industri sektor perikanan siap menghadapi MEA dengan cara meningkatkan nilai tambah produk perikanan yang berdaya saing tinggi.

\section{Harga Output}

Harga output perikanan karena penerapan kebijakan MEA adalah menurunkan harga output barang. Hal ini terjadi karena saat kebijakan MEA diberlakukan maka jumlah permintaan terhadap produk perikanan relatif sama, namun

Tabel 6. Dampak Perubahan Tarif Impor Terhadap Output Perikanan (\%).

Table 6. Impact of Changes in Import Rates on Fisheries Output (\%).

\begin{tabular}{lccc}
\hline \multirow{2}{*}{$\begin{array}{c}\text { Deskripsi/ } \\
\text { Description }\end{array}$} & $\begin{array}{c}\text { Simulasi Dampak Penurunan/Kenaikan Tarif Impor/Impact } \\
\text { Simulation of Increase or Decrease in Import Tariff Increase }\end{array}$ \\
\cline { 2 - 4 } & $\begin{array}{c}\text { Baseline (5\%) I } \\
\text { Baseline (5\%) }\end{array}$ & $\begin{array}{c}\text { Simulasi 1 (10\%)/ } \\
\text { Simulation 1 }\end{array}$ & $\begin{array}{c}\text { Simulasi 2 (-5\%/ } \\
\text { Simulation 2 }\end{array}$ \\
\hline Tuna, Tongkol, dan Cakalang/ Tuna & -0.047 & -0.095 & 0.047 \\
Ikan Tangkap Laut Lainnya/ & & & -0.010 \\
Fisheries Catch & 0.009 & 0.017 & 0.004 \\
Patin/ Catfish & -0.004 & -0.009 & 0.003 \\
Kerapu/ Grouper & -0.003 & -0.006 & 0.003 \\
Rumput Laut/ Seaweed & -0.003 & -0.006 & 0.003 \\
Ikan budidaya lainnya/ Aquaculture & -0.003 & -0.006 & 0.002 \\
Udang/ Prawn & -0.003 & -0.006 & 0.039 \\
Garam/ Salt & -0.036 & -0.070 & -0.067 \\
Ikan kering/ Dried fish & 0.060 & 0.113 & -0.073 \\
Ikan olahan/ Processing fisheries & 0.065 & 0.121 & \\
\hline
\end{tabular}

Sumber: Data I-O 175 sektor yang diagregasi menjadi 75 sektor (diolah)/

Source : I-O data 175 sectors aggregated to 75 sectors (processed) 
Tabel 7. Dampak Perubahan Tarif Impor Terhadap Harga Output Perikanan (\%). Table 7. Impact of Changes on Import Rates on Fisheries Output Price (\%).

\begin{tabular}{|c|c|c|c|}
\hline \multirow{2}{*}{$\begin{array}{l}\text { Deskripsi/ } \\
\text { Description }\end{array}$} & \multicolumn{3}{|c|}{$\begin{array}{l}\text { Simulasi Dampak Penurunan/Kenaikan Tarif Impor/ Impact } \\
\text { Simulation of Increase or Decrease in Import Tariff Increase }\end{array}$} \\
\hline & $\begin{array}{l}\text { Baseline }(5 \%) / \\
\text { Baseline }(5 \%) /\end{array}$ & $\begin{array}{c}\text { Simulasi } 1(10 \%) / \\
\text { Simualtion } 1\end{array}$ & $\begin{array}{l}\text { Simulasi } 2(-5 \%) \\
\text { Simulation } 2\end{array}$ \\
\hline Tuna, Tongkol, dan Cakalang/ Tuna & 0.399 & 0.794 & -.0 .405 \\
\hline $\begin{array}{l}\text { Ikan Tangkap Laut Lainnya/ Fisheries } \\
\text { Catch }\end{array}$ & 0.106 & 0.203 & -0.115 \\
\hline Patin/ Catfish & & & -0.040 \\
\hline Kerapu/ Grouper & 0.036 & 0.067 & -0.050 \\
\hline Rumput Laut/Seaweed & 0.045 & 0.086 & -0.050 \\
\hline Ikan budidaya lainnya/ Aquaculture & 0.045 & 0.086 & -0.050 \\
\hline Udang/ Prawn & 0.052 & 0.100 & -0.057 \\
\hline Garam/ Salt & -0.029 & -0.056 & 0.032 \\
\hline Ikan kering/ Dried fish & 0.100 & 0.192 & -0.110 \\
\hline Ikan olahan/ Processing fisheries & 0.095 & 0.183 & -0.103 \\
\hline
\end{tabular}

Sumber: Data I-O 175 sektor yang diagregasi menjadi 75 sektor (diolah)/

Source : I-O data 175 sectors aggregated to 75 sectors (processed)

kuantitas dan pilihan barang menjadi lebih banyak. Sehingga harga komoditas perikanan menjadi turun, karena penerapan kebijakan MEA, kecuali untuk komoditas garam, penerapan MEA menyebabkan harga garam meningkat menjadi $0,032 \%$

Hal ini terjadi karena saat penerapan MEA tarif impor untuk produk perikanan dari negara ASEAN menjadi turun yang pada akhirnya memudahkan produsen dari negara ASEAN seperti Thailand, Vietnam, dan Malaysia untuk melakukan ekspor perikanan ke Indonesia. Akibatnya, ketersedian ikan dalam negeri menjadi meningkat, sedangkan permintaan ikan cenderung tetap, sehingga terjadi penurunan harga output. Sedangkan meningkatkan permintaan ikan tidak bisa dilakukan jangka pendek, hal ini menyangkut preferensi konsumen. Tidak mudah mengubah preferensi konsumen yang berada di Propinsi DI Yogyakarta, yang tingkat konsumsi ikan sangat rendah yakni hanya sebesar 20,27/kg/ kapita/tahun. Pada tabel 7 di atas penurunan tarif impor sebesar 5\% menyebabkan penurunan harga Ikan Tuna, Tongkol, dan Cakalang turun menjadi $0,405 \%$.

\section{KESIMPULAN DAN IMPLIKASI KEBIJAKAN}

\section{Kesimpulan}

Secara makro, ketika pemerintah membuat kebijakan peningkatan tarif impor untuk komoditas perikanan sebesar 5 akan menurunkan pendapatan pemerintah sebesar $0,200 \%$, menurunkan ekspor sebesar $0,076 \%$, menurunkan impor sebesar
$0,180 \%$. Hal ini disebabkan karena kebijakan tersebut berdampak pada pengurangan surplus konsumen, peningkatan surplus produsen, dan terjadi in efisiensi produksi dan in efisiensi ekonomi. Sebaliknya, penurunan tarif impor perikanan 5\% karena kebijakan MEA, berdampak pada peningkatan pendapatan pemerintah sebesar $0,009 \%$ dan peningkatan ekspor $0,040 \%$. Hal ini disebabkan kebijakan penurunan tarif impor perikanan memaksa industri perikanan melakukan efisiensi biaya produksi supaya memiliki daya saing dengan komoditas perikanan yang diimpor dari negara lain.

Dampak penurunan tarif akibat penerapan MEA atau peningkatan tarif impor terhadap kinerja kelautan perikanan dibagi menjadi terhadap harga output, output, input, ekspor, dan impor. Pertama, penurunan tarif impor sebesar $5 \%$ akibat penerapan kebijakan MEA menyebabkan penurunan harga Ikan Tuna, Tongkol, dan Cakalang turun menjadi $0,405 \%$. Penurunan harga ikan akibat penurunan tarif impor, karena terjadi peningkatan output akibat negara ASEAN mendapatkan kemudahan impor ke Indonesia. Sebaliknya, permintaan ikan cenderung tetap, sehingga terjadi penurunan harga output ikan. Kedua, penurunan tarif impor sebesar 5\% dalam rangka penerapan MEA adalah penurunan output perikanan yang bersifat olahan $(0,073 \%)$ dan produk ikan kering sebesar $0,067 \%$. Hal ini membuktikan sektor kelautan dan perikanan masih memproduksi bahan baku. Ketiga, penurunan tarif impor menyebabkan permintaan input tenaga kerja sektor pengolahan perikanan meningkat sebesar $0,320 \%$. Hal ini disebabkan peningkatan industri 
pengolahan untuk meningkatkan nilai tambah perikanan, sehingga kebutuhan tenaga kerja semakin tinggi. Keempat, ketika kebijakan MEA diterapkan, industri perikanan yang diuntungkan adalah ekspor pada industri pengolahan. Kebijakan penurunan tarif menjadi $0 \%$ yang dulunya $5 \%$, meningkatkan ekspor pengolahan ikan sebesar $66,17 \%$. Kelima, penerapan kebijakan MEA dimana penurun tarif impor sebesar $5 \%$, maka impor perikanan ikan kering dan ikan olahan naik secara signifikan menjadi $11,498 \%$ dan $11,010 \%$. Hal ini mengindikasikan bahwa produk perikanan Indonesia yang di dalam negeri belum memiliki nilai tambah tinggi, sehingga ketika ada kebijakan penurunan tarif impor berdampak pada peningkatan permintaan produk olahan perikanan. Kebijakan Kementerian Kelautan dan Perikanan mendorong investasi asing pada sektor pengolahan ikan dipandang tepat.

\section{Implikasi Kebijakan}

Pada awal penerapan kebijakan penurunan tarif diimplementasikan memang mengurangi pendapatan negara, namun secara jangka panjang akan meningkatkan GDP karena peningkatan ekspor dan pertumbuhan industri yang berdaya saing.

Ketika terjadi peningkatan ouput dan penurunan harga output perikanan, diharapkan pemerintah meningkatkan gerakan Gemarikan, karena meningkatkan permintaan ikan tidak bisa dilakukan jangka pendek, hal ini menyangkut mengubah preferensi konsumen.

Kebijakan Kementerian Kelautan dan Perikanan (KKP), mengenai mengurangi investasi asing pada sektor perikanan tangkap, dan meningkatkan kerja sama investasi asing pada sektor pengolahan perikanan, hal ini dipandang tepat, karena untuk meningkatkan nilai tambah industri perikanan Indonesia.

Diharapkan pemerintah melalui KKP memfasilitasi pelaku usaha perikanan bekerja sama dengan negara anggota ASEAN untuk kerjasama teknologi pengolahan guna peningkatan nilai tambah untuk komoditas ekspor perikanan.

\section{UCAPAN TERIMA KASIH}

Terima kasih kepada pihak-pihak yang telah membantu dalam penelitian terutama dalam penyedian data sekunder, seperti Biro Pusat Statistik. Juga diucapkan terima kasih kepada Bapak Hermanto, dari Pusat Studi Sosial Ekonomi Pertanian, atas sharing ilmu Computable Equillibrium Model. Juga diucapkan terima kasih kepada pihak-pihak yang tidak disebutkan tapi sangat membantu dalam proses penelitian.

\section{DAFTAR PUSTAKA}

Aprianto, E. 2006. Peramalan Dampak Kebijakan Tarif Impor Beras Terhadap Kesejahteraan Pelaku Ekonomi Perdagangan Beras di Jawa Timur. Skripsi. Jurusan Sosial Ekonomi Pertanian. Fakultas Pertanian Jember.

Devarajan, S., J. D. Lewis, and S. Robinson. 1990. Policy Lessons from Trade-Focused, Two-sector Models . Journal of Policy Modeling, 12(4): 625-57

Dixon, P.B., B. R. Parmenter, J. Sutton and D. P. Vincent. 1982. ORANI: A Multisectoral Model of the Australian Economy. North Holland, Amsterdam.

Hulu, E. 1995. Tipologi Model Komputasi Keseimbangan Umum. Ekonomi dan Keuangan Indonesia. Vol. XLIII, No. 1.

Kasan. 2011. Dampak Liberalisasi Perdagangan Sektor Pertanian Terhadap Makro dan Sektoral Ekonomi Indonesia:Pendekatan Model Ekonomi Keseimbangan Umum. Buletin IImiah Perdagangan. 5 (2):123-147

Nicholson, W. 2002. Teori Ekonomi Mikro: Prinsip dan Pengembangannya. Raja Grafindo Persada, Jakarta.

Oktaviani, R. 2011. Model Ekonomi Keseimbangan Umum: Teori dan Aplikasinya di Indonesia. Bogor. IPB Press.

Robinson, S. 1989. Multisectoral Models. Handbook of Development Economics. Vol. II. Edited by H. Chenery, H., and Srinivassan, T.N. Elseiver Publisher, B.V.

Sadoulet, E. and A. de Janvry. 1995. Quantitative Development Policy Analysis. The Jhon Hopkins University Press, London.

Taufikurohman, M. R. 2012. Dampak Kebijakan Fiskal pada Sektor Pertanian terhadap Ekonomi, Tenaga Kerja Pendapatan dan Kemiskinan. Sekolah Pascasarjana, Institut Pertanian Bogor. Bogor.

Wangke, H. 2014. Peluang Indonesia Dalam Masyarakat Ekonomi ASEAN 2015. Info Hubungan Internasional 4 (10):5-8) 
Wibowo, P. M. 2009. Dampak Perdagangan Bebas ASEAN-China terhadap Kinerja Ekonomi Indonesia Khususnya Sektor Pertanian dan Kebutanan: Analisis Simulasi Jangka Panjang. Disertasi. Tidak dipublikasi. Institut Pertanian Bogor. Bogor.

Winardi, W. 2013. Dampak Pembatasan Impor Hortikultura Terhadap Aktivitas Perekonomian, Ting k a t Harga, dan Kesejahteraan. Buletin Ekonomi Moneter dan Perbankan 1 (3):21-41.

Yonariza dan Mahdi. 2013. Potensi Dampak Masyarakat Ekonomi ASEAN 2015 Terhadap S e k t o r Pertanian. Skripsi. Fakultas Ekonomi. Universitas Andalas. Padang. 